(RESEARCH ARTICLE)

\title{
Variations in the levels, source, cancer and non-cancer risks of trace metals in the local and exotic fruits
}

\author{
Ebong Godwin Asukwo *, Etuk Helen Solomon, Dan Emmanuel Udo and Ekpo Keziah James \\ Department of Chemistry, Faculty of Science University of Uyo, P. M. B 1017 Uyo Akwa Ibom State, Nigeria.
}

Publication history: Received on 20 June 2020; revised on 26 June 2020; accepted on 27 June 2020

Article DOI: https://doi.org/10.30574/wjarr.2020.6.3.0224

\begin{abstract}
Local and exotic fruits are generally consumed for their high nutritive values however, they also contain high quantities of harmful substances including trace metals. This work investigated the variations in the levels of $\mathrm{Cd}, \mathrm{Cu}, \mathrm{Fe}, \mathrm{Ni}, \mathrm{Pb}$, and $\mathrm{Zn}$ in the local Citurs sinensis, Persea americana, Citrus paradise, Malus domestica, and Citurs limon are their exotic counterparts. The cancer and non-cancer health risks related to the consumption of both the local and exotic fruits were also examined. The results obtained revealed higher levels of all the metals in the local fruits than in their exotic counterparts however; the mean values of the metals were within their recommended limits by FAO/WHO. Multivariate analysis indicated anthropogenic factor as the major source of trace metals in the studied fruits. The average daily intake rates of the metals were generally lower than their provisional tolerable daily intake limits by FAO/WHO. The study showed that the consumers of local fruits were more vulnerable to health hazard than those consuming the exotic ones. Results for the cancer risk and total cancer risk were generally within the acceptable range of $10^{-6}-10^{-4}$ by USEPA. Though, the consumers of the locally sourced fruits were more exposed to carcinogens.
\end{abstract}

Keywords: Fruits; Carcinogens; cancer and non-cancer risks; Multivariate analysis.

\section{Introduction}

The persistent contamination of our environments has significant negative impact on the quality of our foods. Contaminants in foods including metals affect both the nutritive value and the consumers health negatively [1, 2]. Fruits are used for nutritive values and as cure for different ailments hence, insufficient consumption could result in serious human health problems and death [3, 4]. Fruits are good sources of vitamins, protein, essential elements and minerals to the human system however, they also accumulate high levels of toxic substances including trace metals from the environment $[5,6]$. Trace metals such as $\mathrm{Mn}, \mathrm{Fe}, \mathrm{Ni}, \mathrm{Cu}, \mathrm{Zn}$, and $\mathrm{Cr}$ at their normal limits are necessary for normal activities in organisms [7, 8]. Nevertheless, $\mathrm{Pb}, \mathrm{Cd}, \mathrm{Hg}$, As, and $\mathrm{Ag}$ are not beneficial to any living cell including human rather they are toxic even at a very low concentration $[9,10]$. The essential metals are also toxic at concentrations higher than what is required by the organism $[11,12]$. Reports have shown that trace metals (both the essential and toxic ones) in fruits are mostly from agrochemicals, wastewater, aerial deposition, vehicular emissions, and methods of processing them [13, $14,15,16]$. It has also been reported that plants have the potential of absorbing high level of metals from a contaminated environment $[17,18,19]$. Thus, the intensive use of agrochemicals for the cultivation of fruits globally has impacted negatively on their quality. In the developing Countries such as Nigeria, untreated wastewater is usually used for the irrigation and it may result in the accumulation of trace metals in the edible plants [20,21].

Trace metals including the essential ones can cause harmful effects to the human system [22, 23, 24, 25]. In Akwa Ibom State, both the local and exotic fruits are widely consumed mainly for their nutritive values though, their trace metals content are rarely examined. Consequently, the metal loads of these fruits have not been established and the associated health consequences remain unabated. Invariably, the consumers might be ingesting toxic substances into the body as fruits thus; some of the ailments today could be imported alongside the foreign fruits. The variations in trace metals

\footnotetext{
${ }^{*}$ Corresponding author: Ebong Godwin Asukwo
} 
loads between the locally sourced fruits and their exotic counterparts were investigated in this study. The non-cancer and cancer risks associated with the consumption of these fruits were also examined. The source and the relationships of these metals in the studied fruits were identified using the multivariate analysis. It is hoped that the results of this study shall create awareness on the negative impact associated with the consumption of fruits harvested from a contaminated environment which hitherto was unavailable in the study area. The results shall also serve as a deciding factor for the consumers to rely either on the locally sourced fruits or their exotic counterparts. The negative impact of some agrochemicals on the quality of soil and fruits cultivated there has also been identified.

\section{Material and methods}

\subsection{Sample collection and preparation}

Five local fruits and their exotic counterparts namely: Citrus sinensis (orange), Persea americana (Pear), Citrus paradise (grape), Malus domestica (apple), and Citurs limon (lemon) were bought from supermarkets and Akpan Andem Market both in Uyo Metropolis Akwa Ibom State, Nigeria. Akwa Ibom State is located in the Niger Delta Area of Nigeria and lies between latitudes $4^{0} 32^{\prime}$ and $5^{0} 33^{\prime}$ North and longitudes $7^{0} 25^{\prime}$ and $8^{0} 25^{\prime}$ East. These fruits were carefully washed with tap water first followed by deionized water to clear them of all contaminants adsorbed on the exocarp. The fruits were cut into pieces and oven dried for $48 \mathrm{~h}$ at $100^{\circ} \mathrm{C}$. The dried samples were pulverized with porcelain mortar and pestle to a fine powder and sieved with a $1 \mathrm{~mm}$ sieve. The samples were properly labeled and stored in dry plastic containers for digestion and analysis.

\subsection{Digestion of samples and metal analysis}

$1 \mathrm{~g}$ of the dried sample was digested with a mixture of $\mathrm{HNO}_{3}$ and $\mathrm{HClO}_{4}$ in a ratio of 5:1 until the solution was transparent in nature $[8,26]$. The solution was filtered, poured into a $25 \mathrm{ml}$ flask and stored for metal analysis. An Agilent 710 Inductively Coupled Plasma Optical Emission Spectrometer (ICP-OES) was used for the determination of $\mathrm{Cd}, \mathrm{Cu}, \mathrm{Fe}, \mathrm{Ni}$, $\mathrm{Pb}$, and $\mathrm{Zn}$.

\subsection{Health Risk Assessment}

The possible health risks of trace metals associated with the consumption of the studied local and exotic fruits were evaluated using daily intake rate of the metals [27], hazard quotient (HQ) [28], and hazard index (HI) [29].

Determination of daily Intake of Trace Metals (DIM) in the studied local and exotic fruits was computed using equation (1).

$D I M=\frac{\text { Cmetal } x \text { Dfruit intake }}{\text { Bw average }}$

Where Cmetal represents the concentration $\left(\mathrm{mgkg}^{-1}\right)$ of trace metal in the studied fruits; Dfruit intake is the daily intake rate of the studied fruits which in this study $300 \mathrm{~g} / \mathrm{kg} /$ day was used [30]; Bw average stands for the average body weight of a Nigerian which according to WHO [30] is $62 \mathrm{~kg}$.

2.3.1. Determination of a non-carcinogenic risk index described as hazard quotient (HQ) was calculated using equation (2).

$H Q=\frac{\mathrm{DIM}}{\mathrm{RfD}}$

Where DIM signifies the daily intake rates of the trace metals via the consumption of the studied fruits and RfD stands for the oral reference dose of the metals. The RfD values for $\mathrm{Cd}, \mathrm{Cu}, \mathrm{Fe}, \mathrm{Ni}, \mathrm{Pb}$, and $\mathrm{Zn}$ are 0.001, 0.04, 0.7, 0.02, 0.004, and $0.3 \mathrm{mg} / \mathrm{kg} /$ day, respectively [31].

\subsubsection{Determination of hazard index (HI)}

Hazard index (HI) is the sum of all the hazard quotients (HQs) for the entire trace metals, it was estimated using equation (3).

$\mathrm{HI}=\Sigma H Q=H Q C d+H Q C u+H Q F e+H Q N i+H Q P b+H Q Z n$ 
Where HI represents hazard index and HQ is the hazard quotient of the trace metals. According to Cao et al. [32] when the value of $\mathrm{HI}$ is less than 1, the consumers of the studied fruits are safe but when $\mathrm{HI}$ is equal to or more than 1, then the consumers are at risk.

\subsubsection{Determination of cancer risk (CR) index}

Cancer risk denotes the probability of a consumer developing cancer over a lifetime due the exposure to trace metals (potential carcinogens) via the consumption of the studied fruits. The cancer risk (CR) associated with the exposure to $\mathrm{Cd}, \mathrm{Ni}$, and $\mathrm{Pb}$ through the consumption of the studied fruits over lifetime was calculated using equation (4).

$C R=C S F \times D I M$

Where CSF signifies the cancer slope factor and DIM is the daily intake rates of the trace metals. According to USEPA [33] the values of CSF are $0.38,1.7$, and $0.0085 \mathrm{mg} / \mathrm{kg} /$ day for $\mathrm{Cd}, \mathrm{Ni}$, and $\mathrm{Pb}$, respectively. There were no data for the computation of $\mathrm{CR}$ for $\mathrm{Cu}, \mathrm{Fe}$, and $\mathrm{Zn}$. The acceptable range of predicted lifetime risk for carcinogens by USEPA [34] is $10-4$ (risk of developing cancer is 1 in 10,000 ) to $10-6$ (risk of developing cancer over a lifetime is 1 in $1,000,000$ ).

\subsubsection{Determination of total cancer risk (TCR)}

The probability of a consumer developing cancer when exposed to several trace metals (carcinogens) via the consumption of a particular fruit was adopted, and the sum of the different trace metals increasing risk was computed using equation (5).

Total cancer risk $=\Sigma \mathrm{CR}$

Where CR denotes the cancer risk.

\subsection{Statistical analysis}

The data obtained in this study were treated for the mean and standard deviation using IBM SPSS Statistics 20. The principal component analysis (PCA) was done by calculating the data with Varimax Factor analysis. The cluster analysis (CA) of metals determined was done by categorizing the results in Hierarchical Cluster Dendrogram plots with IBM SPSS Statistics 20.

\section{Results and discussion}

Table 1 Level of Trace metals in Local fruits and Exotic fruits

\begin{tabular}{|c|c|c|c|c|c|c|c|}
\hline & & Cd & $\mathbf{C u}$ & $\mathbf{F e}$ & $\mathbf{N i}$ & $\mathbf{P b}$ & Zn \\
\hline Citrus & Local & 0.023 & 0.021 & 0.300 & 0.015 & 0.005 & 0.963 \\
\hline sinensis & Exotic & 0.032 & 0.030 & 0.221 & 0.005 & 0.002 & 1.248 \\
\hline Persea & Local & 0.056 & 0.035 & 0.218 & 0.023 & 0.002 & 1.633 \\
\hline americana & Exotic & 0.041 & 0.029 & 0.249 & 0.007 & 0.001 & 1.405 \\
\hline Citrus & Local & 0.026 & 0.040 & 0.257 & 0.020 & 0.004 & 1.817 \\
\hline paradise & Exotic & 0.038 & 0.019 & 0.189 & 0.010 & 0.003 & 1.742 \\
\hline Malus & Local & 0.091 & 0.017 & 0.193 & 0.017 & 0.003 & 0.952 \\
\hline domestica & Exotic & 0.084 & 0.037 & 0.186 & 0.006 & 0.002 & 1.059 \\
\hline \multirow[t]{2}{*}{ Citrus limon } & Local & 0.086 & 0.039 & 0.292 & 0.064 & 0.003 & 1.748 \\
\hline & Exotic & 0.075 & 0.019 & 0.323 & 0.008 & 0.005 & 0.893 \\
\hline Min & & 0.023 & 0.017 & 0.186 & 0.005 & 0.001 & 0.893 \\
\hline Max & & 0.091 & 0.040 & 0.323 & 0.064 & 0.005 & 1.817 \\
\hline SD & & 0.025 & 0.009 & 0.047 & 0.017 & 0.001 & 0.350 \\
\hline Mean & & 0.055 & 0.029 & 0.243 & 0.018 & 0.003 & 1.346 \\
\hline MRL & & 0.10 & 2.00 & 0.30 & 0.20 & 0.05 & 5.00 \\
\hline
\end{tabular}




\subsection{Trace metals in the studied fruits}

Cadmium (Cd) in the studied fruits varied between 0.023 and $0.091 \mathrm{mgkg}^{-1}$ in the local Citrus sinensis and Malus domestica, respectively. This range is higher than $0.001-0.006 \mathrm{mgkg}^{-1}$ obtained by Sobukola et al. [36] but lower than 0.01 to $0.362 \mathrm{mgkg}^{-1}$ reported by Elbagermi et al. [23]. The results revealed higher levels of $\mathrm{Cd}$ in the local fruits than in their exotic counterparts except in Citrus sinensis and Citrus paradise. This could be attributed to the class and quantity of agrochemicals used by local farmers [16,37]. The method of processing and handling of the local fruits could also elevate their levels of trace metals $[14,38]$. The mean value of $\mathrm{Cd}\left(0.055 \pm 0.025 \mathrm{mgkg}^{-1}\right)$ is lower than the $0.10 \mathrm{mgkg}^{-1}$ recommended limit in fruits by FAO/WHO [35]. Consequently, the consumption of the studied fruits might not result in health problems associated with Cd toxicity. However, as a toxic element to both plants and animals its presence in our environment should be controlled to forestall serious problems along the food chain as reported by Divrikli et al. [1].

Copper $(\mathrm{Cu})$ is an essential element for plants and animals but at higher concentrations it could be harmful [39]. Levels of Cu ranged from $0.017 \mathrm{mgkg}^{-1}$ in local Malus domestica to $0.040 \mathrm{mgkg}^{-1}{ }^{1} \mathrm{n}$ local Citrus paradise, respectively. This range is lower than $0.04-0.22 \mathrm{mgkg}^{-1}$ and $2.4-25.0 \mathrm{mg} \mathrm{kg}^{-1}$ obtained by Ezeonyejiaku and Obiakor [40] and Aydinalp and Marinova [41], respectively. The concentrations of Cu were generally higher in the local than in the exotic fruits except for Citrus sinensis and Malus domestica. This could be attributed to the variations in anthropogenic factors between the local and foreign environments as opined by [42]. The mean value of $\mathrm{Cu}\left(0.029 \pm 0.009 \mathrm{mgkg}^{-1}\right)$ obtained is lower than $2.00 \mathrm{mgkg}^{-1}$ recommended limit by FAO/WHO [35]. Hence, the consumers of the studied fruits may not experience $\mathrm{Cu}$ toxicity and its attendants' health problems.

The levels of iron (Fe) in the studied fruits varied between $0.186 \mathrm{mgkg}^{-1}$ in exotic Malus domestica and $0.323 \mathrm{mgkg}^{-1} \mathrm{in}$ exotic Citrus limon. This range is lower than $1.10-36.0 \mu \mathrm{g} / \mathrm{g}$ and $2.50-5.60 \mathrm{mgkg}^{-1}$ reported by Mehari et al. [43] and Yami et al. [44], respectively. Fe is essential for all living organisms and its deficiency is harmful to both plants and animals $[45,46]$. The levels of Fe were higher in all the local fruits than in the exotic ones except for Persea americana and Citrus limon. This could be attributed to the variations in the soil properties and anthropogenic factor [47, 48]. The mean value of Fe $\left(0.243 \pm 0.047 \mathrm{mgkg}^{-1}\right)$ is lower than $0.300 \mathrm{mgkg}^{-1}$ recommended by FAO/WHO [35] for fruits. Consequently, all the studied fruits were suitable for consumption except exotic Citrus limon which had Fe concentration higher than the recommended limit.

Nickel (Ni) in the studied fruits ranged from $0.005 \mathrm{mgkg}^{-1}$ in exotic Citrus sinensis to $0.064 \mathrm{mgkg}^{-1}$ in the local Citrus limon. This range is consistent with $0.001-0.061 \mathrm{mgkg}^{-1}$ obtained by Sobukola et al. [36] but lower than $0.000-0.400$ $\mathrm{mgkg}^{-1}$ and $0.000-0.475 \mathrm{mgkg}^{-1}$ reported by Guerra et al. [49] and Omoyajowo et al. [50], respectively. The levels of Ni were generally higher in the local than in the exotic fruits. This could be the consequence of disparity in both the natural and anthropogenic factors $[14,48]$. The average $\mathrm{Ni}$ level obtained $\left(0.018 \pm 0.017 \mathrm{mgkg}^{-1}\right)$ is much lower than $0.20 \mathrm{mgkg}$ ${ }^{1}$ recommended limit for fruits by FAO/WHO [35]. The high standard deviation reported is an indication that, more of the values were far from the mean [51].

The level of lead (Pb) in the studied fruits varied between $0.001 \mathrm{mgkg}^{-1}$ in exotic Persea americana and $0.005 \mathrm{mgkg}^{-1} \mathrm{in}^{-1}$ local Citrus sinensis and exotic Citrus limon. The obtained levels of $\mathrm{Pb}$ is lower than 0.01 to $0.87 \mathrm{mgkg}^{-1}$ and $1.69-5.80$ mgkg-1 $^{-1}$ reported by Radwan and Salama [52] and Ihesinachi and Eresiya [53], respectively. Nevertheless, the range reported in this study is higher than the below detectable limit (BDL) obtained in all the fruits analyzed by Yami et al. [44]. The overall results revealed higher levels of $\mathrm{Pb}$ in the local than in the exotic fruits except for Citrus limon. This could be attributed to the impact of inorganic fertilizers and aerial depositions [13,54]. The mean value of Pb recorded $\left(0.003 \pm 0.001 \mathrm{mgkg}^{-1}\right)$ is lower than $0.05 \mathrm{mgkg}^{-1}$ recommended limit in fruits by FAO/WHO [35]. Thus, the consumption of these fruits might not cause serious health problems associated with $\mathrm{Pb}$ toxicity however; as a toxic element its availability should be drastically reduced to avoid bioaccumulation along the food chain.

The concentrations of zinc (Zn) in the studied fruits ranged from $0.893 \mathrm{mgkg}^{-1}$ in exotic Citrus limon to $1.817 \mathrm{mgkg}^{-1} \mathrm{in}$ local Citrus paradise. The reported range is higher than 0.039 - $0.082 \mathrm{mgkg}^{-1}$ reported by Sobukola et al. [36] but, lower than 6.31 - $49.3 \mathrm{mgkg}^{-1}$ obtained by Alzahrani et al. [6]. Higher concentrations of $\mathrm{Zn}$ were reported in the local Persea americana, Citrus paradise, and Citrus limon than in the exotic ones while the reverse was the case in Citrus sinensis and Malus domestica. This variation could be attributed to both the natural and anthropogenic factors. $\mathrm{Zn}$ is an essential element for all living organisms including human but, it could be toxic at a higher concentration $[55,56]$. The mean value of Zn obtained (1.346 $\left.\pm 0.350 \mathrm{mgkg}^{-1}\right)$ is below $2.00 \mathrm{mgkg}^{-1}$ limit by FAO/WHO [35]. Hence, the levels of Zn in all the studied fruits might not pose serious health challenge to the consumers. Among the metals determined in the studied fruits, $\mathrm{Zn}$ had the highest concentration as also observed by Radwan and Salama [52]. 
The results obtained also indicated that although there were variations in the level of these metals between the local and exotic fruits. The concentrations of the metals determined followed a similar order $\mathrm{Zn}>\mathrm{Fe}>\mathrm{Cd}>\mathrm{Cu}>\mathrm{Ni}>\mathrm{Pb}$.

Table 2 DIM of trace metals in the local and exotic fruits

\begin{tabular}{llllll}
\hline & Local fruits & & & & \\
\hline & Citrus sinensis & Persea americana & Citrus paradise & Malus domestica & Citrus limon \\
\hline $\mathrm{Cd}$ & $1.1 \mathrm{E}-04$ & $3.0 \mathrm{E}-04$ & $1.3 \mathrm{E}-04$ & $4.4 \mathrm{E}-04$ & $4.2 \mathrm{E}-04$ \\
$\mathrm{Cu}$ & $1.0 \mathrm{E}-04$ & $2.0 \mathrm{E}-04$ & $1.9 \mathrm{E}-04$ & $8.0 \mathrm{E}-05$ & $1.9 \mathrm{E}-04$ \\
$\mathrm{Fe}$ & $1.0 \mathrm{E}-03$ & $1.0 \mathrm{E}-03$ & $1.2 \mathrm{E}-03$ & $9.0 \mathrm{E}-04$ & $1.4 \mathrm{E}-03$ \\
$\mathrm{Ni}$ & $7.0 \mathrm{E}-05$ & $1.0 \mathrm{E}-04$ & $9.7 \mathrm{E}-05$ & $8.0 \mathrm{E}-05$ & $3.1 \mathrm{E}-04$ \\
$\mathrm{~Pb}$ & $2.0 \mathrm{E}-05$ & $9.0 \mathrm{E}-06$ & $1.9 \mathrm{E}-05$ & $2.0 \mathrm{E}-05$ & $1.5 \mathrm{E}-04$ \\
$\mathrm{Zn}$ & $5.0 \mathrm{E}-03$ & $8.0 \mathrm{E}-03$ & $8.8 \mathrm{E}-03$ & $4.6 \mathrm{E}-03$ & $8.4 \mathrm{E}-03$ \\
\hline $\mathrm{Exotic}$ fruits & & & & $3.6 \mathrm{E}-04$ \\
\hline $\mathrm{Cd}$ & $2.0 \mathrm{E}-04$ & $1.9 \mathrm{E}-04$ & $2.0 \mathrm{E}-04$ & $4.0 \mathrm{E}-04$ & $9.0 \mathrm{E}-05$ \\
$\mathrm{Cu}$ & $2.0 \mathrm{E}-04$ & $2.0 \mathrm{E}-04$ & $9.0 \mathrm{E}-05$ & $2.0 \mathrm{E}-04$ & $1.5 \mathrm{E}-03$ \\
$\mathrm{Fe}$ & $1.0 \mathrm{E}-03$ & $1.2 \mathrm{E}-03$ & $9.0 \mathrm{E}-04$ & $9.0 \mathrm{E}-04$ & $3.8 \mathrm{E}-05$ \\
$\mathrm{Ni}$ & $2.0 \mathrm{E}-05$ & $3.4 \mathrm{E}-05$ & $4.8 \mathrm{E}-05$ & $2.05 \mathrm{E}-05$ & $2.0 \mathrm{E}-05$ \\
$\mathrm{~Pb}$ & $9.0 \mathrm{E}-06$ & $4.8 \mathrm{E}-06$ & $1.4 \mathrm{E}-05$ & $9.0 \mathrm{E}-06$ & $4.0 \mathrm{E}-03$ \\
$\mathrm{Zn}$ & $6.0 \mathrm{E}-03$ & $6.8 \mathrm{E}-03$ & $8.0 \mathrm{E}-03$ & $5.0 \mathrm{E}-03$ & \\
\hline
\end{tabular}

\subsection{Daily intake of trace metals via the consumption of local and exotic fruits}

The mean DIM values for $\mathrm{Cd}$ are 2.80E-04 and 2.7E-04 mg for the local and exotic fruits, respectively. These values represent 28 and $27 \%$ of the RfD value of $0.001 \mathrm{mg}$ per day for a $62 \mathrm{~kg}$ adult for local and exotic fruits, respectively [57]. The daily intake of $\mathrm{Cd}$ via the local and exotic fruits as shown in Table 2 are lower than the provisional tolerable daily intake of $0.06 \mathrm{mg}$ by FAO/WHO [58]. Thus, the consumption of these fruits might not pose any health risk related to Cd toxicity. However, the consumers of the local fruits are more vulnerable to Cd toxicity. Malus domestica contributed the greatest $\mathrm{Cd}$ intake via the consumption of both the local and exotic fruits accounting for 31 and $30 \%$, respectively of the DIM.

The average DIM values for $\mathrm{Cu}$ are 1.52E-04 and 1.56E-04 mg for the local and exotic fruits, respectively. The mean DIM value in the local fruits represents $0.38 \%$ while that of exotic accounted for $0.39 \%$ of the RfD value of $0.04 \mathrm{mg}$ for a 62 $\mathrm{kg}$ adult [57]. Thus, the consumers of the exotic fruits are more exposed to $\mathrm{Cu}$ than those consuming their local counterparts. The values obtained for DIM in Table 2 through the consumption of both classes of fruits are lower than the recommended PTDI of $3.0 \mathrm{mg}$ by FAO/WHO [58]. Consequently, the consumers of these fruits are free of risk associated with $\mathrm{Cu}$ toxicity however, could be deficient of this essential element. Persea americana is the greatest route through which the consumers of these fruits are exposed to $\mathrm{Cu}$ with $26 \%$ each of the total DIM.

The daily intake rates of Fe varied as follows: 9.0E-04 - 1.4E-03 mg and 1.1E-03 and 9.0E-03 mg for the local and exotic fruits, respectively (Table 2). The mean DIM values for Fe via the consumption of the local and exotic fruits is $1.10 \mathrm{E}-03$ mg each. This represents $0.16 \%$ each of the RfD value of $0.7 \mathrm{mg}$ per day for a $62 \mathrm{~kg}$ adult [58]. Consequently, the consumers of both the studied local and exotic fruits will have the same level of exposure to Fe. The values obtained for DIM via the consumption of both classes of fruits are lower than $0.70 \mathrm{mg}$ per day for a $62 \mathrm{~kg}$ adult by WHO [58]. Hence, the consumers may not be exposed to high level of Fe and its attendants' health problems. The DIM values for both categories of the studied fruits are also lower than the stipulated PTDI limit of $48 \mathrm{mg}$ by FAO/WHO [59]. This also confirms the deficient nature of the much-needed Fe in these fruits thus, the consumers should complement from other sources. Amongst the studied fruits, Citrus limon contributed highest level of Fe to the total DIM with 26 and $27 \%$ for the local and exotic fruits, respectively. 
The mean DIM values for $\mathrm{Ni}$ in the studied local and exotic fruits are 1.31E-04 and 3.20E-05 mg, respectively. Based on the results in Table 2, the consumers of the studied local fruits are more exposed to Ni than the consumer of the exotic ones. These mean values represent 0.66 and $0.16 \%$ of the RfD value of $0.1 \mathrm{mg}$ per day for a $62 \mathrm{~kg}$ adult [58]. The values of DIM for Ni in Table 2 vary from 7.0E-05 to 3.1E-04 mg and 2.0E-05 to 4.8E-05 mg for the local and exotic fruits, correspondingly. These values are less than $0.02 \mathrm{mg}$ per day for a $62 \mathrm{~kg}$ adult recommended by WHO [58]. Hence, the consumers of both classes of the studied fruits might not be exposed to Ni toxicity though there are other routes of exposure to metal toxicity. The values obtained are also lower than the recommended PTDI range of $0.1-0.3 \mathrm{mg}$ by FAO/WHO [59]. Thus, the consumers might not be at risk as far as $\mathrm{Ni}$ is concerned. Citus limon was the highest contributor of $\mathrm{Ni}$ in the local fruits with $47 \%$ while Citrus paradise contributed the highest in the exotic fruits with $30 \%$ to the total DIM.

The average values of daily intake rates of $\mathrm{Pb}$ are $4.36 \mathrm{E}-05$ and $1.14 \mathrm{E}-05 \mathrm{mg}$ for the local and exotic fruits, correspondingly. Consequently, the consumers of the studied local fruits are more exposed to $\mathrm{Pb}$ than the consumers of their exotic counterparts. The mean DIM values of $\mathrm{Pb}$ in the local and exotic fruits represent 1.1 and $0.29 \%$ of the RfD value of $0.004 \mathrm{mg}$ per day for a $62 \mathrm{~kg}$ adult [58]. The values of DIM for Pb varied from 9.0E-06 to $1.5 \mathrm{E}-04 \mathrm{mg}$ in the local fruits and 4.8E-06 to 2.0E-05 mg in the exotic fruits. These values are lower than $0.004 \mathrm{mg}$ per day for an adult by WHO [58]. Hence, these fruits are safe for human consumption with respect to $\mathrm{Pb}$ but, as a highly toxic metal bioaccumulation should avoided. The values of DIM reported for Pb are less than the recommended PTDI value of $0.214 \mathrm{mg}$ as well [59]. This affirms the safe nature of the studied fruits for human consumption. The highest contributors of Pb was Citrus limon for both the local and exotic fruits with 69 and 35\%, respectively of the total DIM.

The mean values recorded for the daily intake of $\mathrm{Zn}$ via the consumption of local and exotic fruits are $6.96 \mathrm{E}-03$ and 5.96E-03 mg, respectively. Accordingly, the consumers of the studied exotic fruits are less exposed to $\mathrm{Zn}$ than the consumers of their local species. The average DIM values of $\mathrm{Zn}$ in the exotic and local fruits contributed 1.99 and $2.32 \%$ of the RfD value of $0.3 \mathrm{mg}$ per day for a $62 \mathrm{~kg}$ adult [58]. The range of DIM for Zn ranged from $4.60 \mathrm{E}-03$ to $8.80 \mathrm{E}-03 \mathrm{mg}$ for local fruits and 4.0E-03 to 8.0E-03 mg for the exotic ones (Table 2). These values are less than $0.3 \mathrm{mg}$ per day recommended for a $62 \mathrm{~kg}$ adult by WHO [58]. Consequently, these fruits are deficient of this essential element and should be complemented from other sources of food. These values are also lower than $60 \mathrm{mg}$ the recommended PTDI value by FAO/WHO [58]. Hence, these fruits might not serve as a good source of Zn for the consumers although, the consumers of the local fruits are better off. The major source of $\mathrm{Zn}$ to the consumers in this study was Citrus paradise for both the local and exotic fruits contributing 24 and 13\%, respectively to the total DIM obtained.

The daily intake rates of trace metals followed the order $\mathrm{Zn}>\mathrm{Fe}>\mathrm{Cd}>\mathrm{Cu}>\mathrm{Ni}>\mathrm{Pb}$ for the local fruits and $\mathrm{Zn}>\mathrm{Pb}>\mathrm{Fe}$ $>\mathrm{Cd}>\mathrm{Cu}>\mathrm{Ni}$ for the exotic fruits, respectively. Thus, both the local and exotic fruits exposed the consumers more to Zn than other metals.

Table 3 THQs and HI of trace metals in the local and exotic fruits

\begin{tabular}{llllll}
\hline \multicolumn{7}{c}{ HQs for local fruits } \\
\hline & Citrus sinensis & Persea americana & Citrus paradise & Malus domestica & Citrus limon \\
\hline $\mathrm{Cd}$ & $1.1 \mathrm{E}-01$ & $0.2 .7 \mathrm{E}-01$ & $1.3 \mathrm{E}-01$ & $4.4 \mathrm{E}-01$ & $4.2 \mathrm{E}-01$ \\
$\mathrm{Cu}$ & $3.0 \mathrm{E}-03$ & $4.0 \mathrm{E}-03$ & $4.0 \mathrm{E}-03$ & $2.0 \mathrm{E}-03$ & $5.0 \mathrm{E}-03$ \\
$\mathrm{Fe}$ & $2.0 \mathrm{E}-03$ & $1.0 \mathrm{E}-03$ & $1.0 \mathrm{E}-03$ & $1.0 \mathrm{E}-03$ & $2.0 \mathrm{E}-03$ \\
$\mathrm{Ni}$ & $3.0 \mathrm{E}-03$ & $6.0 \mathrm{E}-03$ & $5.0 \mathrm{E}-03$ & $4.0 \mathrm{E}-03$ & $2.0 \mathrm{E}-03$ \\
$\mathrm{~Pb}$ & $6.0 \mathrm{E}-03$ & $2.0 \mathrm{E}-03$ & $5.0 \mathrm{E}-03$ & $3.6 \mathrm{E}-03$ & $3.6 \mathrm{E}-03$ \\
$\mathrm{Zn}$ & $1.2 \mathrm{E}-02$ & $2.7 \mathrm{E}-02$ & $2.9 \mathrm{E}-02$ & $1.5 \mathrm{E}-02$ & $2.8 \mathrm{E}-02$ \\
$\mathrm{HI}$ & 0.14 & 0.31 & 0.17 & 0.47 & 0.46 \\
\hline \multicolumn{5}{c}{ HQs for exotic fruits } \\
$\mathrm{Cd}$ & $1.5 \mathrm{E}-01$ & $2.0 \mathrm{E}-01$ & $1.8 \mathrm{E}-01$ & $4.1 \mathrm{E}-01$ & $2.0 \mathrm{E}-01$ \\
$\mathrm{Cu}$ & $4.0 \mathrm{E}-04$ & $3.5 \mathrm{E}-03$ & $3.0 \mathrm{E}-03$ & $2.0 \mathrm{E}-03$ \\
$\mathrm{Fe}$ & $1.5 \mathrm{E}-03$ & $1.7 \mathrm{E}-03$ & $1.3 \mathrm{E}-03$ & $1.3 \mathrm{E}-03$ & $1.9 \mathrm{E}-03$ \\
$\mathrm{Ni}$ & $1.2 \mathrm{E}-03$ & $1.6 \mathrm{E}-03$ & $2.4 \mathrm{E}-03$ & $1.6 \mathrm{E}-03$ & $6.0 \mathrm{E}-03$ \\
$\mathrm{~Pb}$ & $2.0 \mathrm{E}-03$ & $1.2 \mathrm{E}-03$ & $4.0 \mathrm{E}-03$ & $3.0 \mathrm{E}-03$ & $1.4 \mathrm{E}-02$ \\
$\mathrm{Zn}$ & $2.0 \mathrm{E}-02$ & $2.2 \mathrm{E}-02$ & $2.9 \mathrm{E}-02$ & $1.8 \mathrm{E}-02$ & 0.39 \\
$\mathrm{HI}$ & 0.18 & 0.23 & 0.22 & 0.44 & \\
\hline
\end{tabular}




\subsection{Hazard quotient (HQ)}

Hazard quotient is an index related to a long-term exposure to these metal contaminants through the consumption of the studied fruits. According to Wang et al. [59] it is not used to quantify the risk involved but it specifies the degree of concern. The HQ values for the trace metals determined in the studied fruits are shown in Table 3. The HQ values of Cd ranged from 0.11 to 0.44 and 0.15 to 0.41 in the local and exotic fruits, respectively. The highest HQ values of the local and exotic fruits were obtained in Malus domestica. Thus, the consumption of Malus domestica from both the local and foreign sources might expose the consumers to Cd toxicity over time [60].

The HQ values for $\mathrm{Cu}$ in the local and exotic fruits ranged as follows: 2.0E-03 - 5.0E-03 and 4.0E-04 - 5.0E-03, respectively. The fruits with highest $\mathrm{HQ}$ values of $\mathrm{Cu}$ in the local and exotic fruits were Citrus limon and Malus domestica, respectively. $\mathrm{Cu}$ is an essential element hence, more of it might be required by the consumers as its deficiency in the human system could also result in serious health problems [61]. However, the bioaccumulation of $\mathrm{Cu}$ in fruits should be controlled to avoid damage to the liver and kidney of the consumers [62].

The HQ values of Fe in both the local and exotic fruits varied from 1.0E-03 to 2.0E-03 and 1.3E-03 to 2.0E-03, respectively. The highest HQ value of Fe in the local fruits was obtained in Citrus sinensis and Citrus limon while Citrus limon had the highest HQ value of Fe among the exotic fruits. As an essential element with HQ values less than 1, there might be no tendency for Fe toxicity and the related problems in the consumers. Although, the low and excessive levels of Fe in fruits have their related health problems $[63,64]$.

Ranges of 2.0E-03 - 6.0E-03 and 1.2E-03 - 2.4E-03 were obtained for the HQ values of Ni in the local and exotic fruits, respectively. The highest $\mathrm{HQ}$ value of $\mathrm{Ni}$ in the local fruits was obtained in Persea americana whereas, Citrus paradise had the highest HQ value of $\mathrm{Ni}$ in the exotic fruits. Accordingly, the consumers of the local Persea americana and exotic Citrus paradise might be exposed to health problems associated with Ni toxicity over time [65].

The values of hazard quotient for $\mathrm{Pb}$ in the local and exotic fruits ranged from 2.0E-03 to 6.0E-03 and $1.2 \mathrm{E}-03$ to $6.0 \mathrm{E}-$ 03, correspondingly. The highest HQ values of $\mathrm{Pb}$ in the local and exotic fruits were obtained in Citrus sinensis and Citrus limon, respectively. $\mathrm{Pb}$ is not an essential element hence, a prolonged consumption of these fruits might pose serious health risk to the consumers as reported by Guerra et al. [49].

The HQ values of $\mathrm{Zn}$ in the local and exotic fruits varied from $1.2 \mathrm{E}-02$ to $2.9 \mathrm{E}-02$ and $1.4 \mathrm{E}-02$ to $2.9 \mathrm{E}-02$, respectively. The highest HQ values for $\mathrm{Zn}$ in both the local and exotic fruits were obtained in Citrus paradise. Thus, the consumption of these fruits might expose the consumers to the required level of $\mathrm{Zn}$ in the human body but its toxicity should be avoided to forestall health challenges reported by Roohani et al. [66].

Generally, the HQ values for the metals were lower than 1 consequently, these fruits may not pose any non-cancer risk to the consumers. Although, the HQ value of the metals is directly proportional to the potential human health risk [67, 68].

\subsection{Hazard index (HI) associated with the exposure to trace metals}

In assessing the human health risk associated with all the trace metals determined in the studied fruits, the idea of total hazard index (HI) was introduced. When an HI value is less than 1, it shows that consumption of the studied fruits might not result in non-carcinogenic risk. However, when the HI value is equal to or higher than 1 , there is likelihood that serious health problems may occur [32,49]. The HI values of the studied local and toxic fruits are indicated in Table 3. The HI values of the trace metals in local fruits ranged from 0.14 in Citrus sinensis to 0.47 in Malus domestica. Whereas, the HI values of the metals in the exotic fruits varied between 0.18 in Citrus sinensis and 0.44 in Malus domestica. The HI values of the local and exotic fruits followed the order M. domestica $>$ C. limon $>$ P. americana $>$. paradise $>C$. sinensis. The general values of HI for all the fruits were below 1 hence, the consumption of these fruits may not pose any noncarcinogenic risk. Though, the consumers of the local fruits could be more susceptible to non-carcinogen risks than those consuming their exotic counterparts. 
Table 4 Cancer risk and total cancer risk of the trace metals in the local and exotic fruits

\begin{tabular}{|c|c|c|c|c|c|}
\hline \multicolumn{6}{|c|}{ Local fruits } \\
\hline & Citrus sinensis & Persea americana & Citrus paradise & Malus domestica & Citrus limon \\
\hline $\mathrm{Cd}$ & $4.18 \mathrm{E}-05$ & $1.14 \mathrm{E}-04$ & $4.94 \mathrm{E}-05$ & $1.67 \mathrm{E}-04$ & $1.60 \mathrm{E}-04$ \\
\hline $\mathrm{Cu}$ & - & - & - & - & - \\
\hline $\mathrm{Fe}$ & - & - & - & - & - \\
\hline $\mathrm{Ni}$ & $1.19 \mathrm{E}-04$ & $1.70 \mathrm{E}-04$ & $1.65 \mathrm{E}-04$ & $1.36 \mathrm{E}-04$ & $5.27 \mathrm{E}-04$ \\
\hline $\mathrm{Pb}$ & $1.70 \mathrm{E}-06$ & $7.65 \mathrm{E}-07$ & $1.62 \mathrm{E}-07$ & $1.70 \mathrm{E}-07$ & $1.28 \mathrm{E}-07$ \\
\hline $\mathrm{Zn}$ & - & - & - & - & - \\
\hline$\Sigma C R$ & $1.63 \mathrm{E}-04$ & $2.85 \mathrm{E}-04$ & $2.15 \mathrm{E}-04$ & $3.03 \mathrm{E}-04$ & $6.87 \mathrm{E}-04$ \\
\hline \multicolumn{6}{|c|}{ Exotic fruits } \\
\hline $\mathrm{Cd}$ & $7.60 \mathrm{E}-05$ & $7.22 \mathrm{E}-05$ & $7.60 \mathrm{E}-05$ & $1.52 \mathrm{E}-04$ & $1.37 \mathrm{E}-04$ \\
\hline $\mathrm{Cu}$ & - & - & - & - & - \\
\hline $\mathrm{Fe}$ & - & - & - & - & - \\
\hline $\mathrm{Ni}$ & $3.40 \mathrm{E}-05$ & $5.78 \mathrm{E}-05$ & $8.16 \mathrm{E}-05$ & $3.40 \mathrm{E}-05$ & $6.46 \mathrm{E}-05$ \\
\hline $\mathrm{Pb}$ & $7.65 \mathrm{E}-08$ & $4.08 \mathrm{E}-08$ & $1.19 \mathrm{E}-07$ & $7.65 \mathrm{E}-08$ & $1.70 \mathrm{E}-07$ \\
\hline $\mathrm{Zn}$ & - & - & - & - & - \\
\hline$\Sigma C R$ & $1.10 \mathrm{E}-04$ & $1.30 \mathrm{E}-04$ & $1.58 \mathrm{E}-04$ & $1.86 \mathrm{E}-04$ & $2.02 \mathrm{E}-04$ \\
\hline
\end{tabular}

\subsection{The Cancer Risk (CR)}

In this study, $\mathrm{Cd}, \mathrm{Ni}$, and $\mathrm{Pb}$ were of special concern due to their high carcinogenic risk [69]. The acceptable range of predicted lifetime risk for carcinogens by USEPA [34] is $10^{-6}(1$ in $1,000,000)$ to $10^{-4}$ (1 in 10,000$)$. Substances with risk factor below $10^{-6}$ may be ignored for further consideration as a substance of concern. The results obtained for the cancer risk (CR) of these metals via consumption of the studied fruits are shown in Table 4. The predictable lifetime risk to cancer because of $\mathrm{Cd}$ intake via the consumption of the local and exotic fruits varied from 4.18E-05 to 1.67E-04 and 7.22E-05 to 1.52E-04, respectively. These values are within the safe range of lifetime risk to cancer [34]. However, the cancer risk associated with the consumption of the local fruits are higher. The cancer risk values for Ni through the consumption of local and exotic fruits ranged from 1.19E-04 to 5.27E-04 and 3.40E-05 to 8.16E-05, respectively. Based on USEPA [34] recommendations, these values are within the permissible range by USEPA [34] though, higher cancer risk values were recorded for $\mathrm{Ni}$ via the consumers of the local fruits. The cancer risk due to $\mathrm{Pb}$ intake through the consumption of the local and exotic fruits varied from 1.28E-07 to 1.70E-06 and 4.08E-08 to 1.70E-07, correspondingly. These values are below the acceptable range and should be ignored except for Citrus sinensis with a value of $1.70 \mathrm{E}-06$. Although, the CR values obtained may not pose any cancer risk to the consumers, the local fruits might have exposed the consumers to a higher degree of risk than the exotic ones. In other words, the studied exotic fruits would have been much safer than their local counterparts. There were insufficient data for the carcinogenic potentials of $\mathrm{Cu}, \mathrm{Fe}$, and $\mathrm{Zn}$ for the computation of their cancer risk in this study [33].

\subsection{Total Cancer Risk (TCR)}

The results for the total cancer risk in Table 4 indicate a range of $1.63 \mathrm{E}-04-6.87 \mathrm{E}-04$ for the local fruits and $1.10 \mathrm{E}-04-$ 2.02E-04 for the exotic fruits, respectively. These values are within the threshold range by USEPA [34]. Thus, the consumption of both the local and exotic fruits may not expose the consumers to cancer risk. Nevertheless, the probability of exposure to cancer risk is higher in the consumers of local fruits than in the consumers of the exotic ones. 
Table 5 Total Variance Explained for trace metals in the studied local and exotic fruits

\begin{tabular}{|c|c|c|c|c|c|c|c|c|c|}
\hline \multirow{3}{*}{ Component } & \multicolumn{9}{|c|}{ Local fruits } \\
\hline & \multicolumn{3}{|c|}{ Initial Eigen values } & \multicolumn{2}{|c|}{$\begin{array}{l}\text { Extraction Sums } \\
\text { Loadings }\end{array}$} & \multirow{2}{*}{$\begin{array}{c}\text { of Squared } \\
\begin{array}{c}\text { Cumulative } \\
\%\end{array}\end{array}$} & \multicolumn{2}{|c|}{$\begin{array}{ll}\text { Rotation } & \text { Sums } \\
\text { Loadings } & \end{array}$} & of Squared \\
\hline & Total & $\begin{array}{l}\% \quad \text { of } \\
\text { Variance }\end{array}$ & $\begin{array}{c}\text { Cumulative } \\
\%\end{array}$ & Total & $\begin{array}{c}\% \quad \text { of } \\
\text { Variance }\end{array}$ & & Total & $\begin{array}{c}\% \quad \text { of } \\
\text { Variance }\end{array}$ & $\begin{array}{c}\text { Cumulative } \\
\%\end{array}$ \\
\hline 1 & 2.69 & 44.86 & 44.86 & 2.69 & 44.86 & 44.86 & 2.36 & 39.34 & 39.34 \\
\hline 2 & 2.16 & 35.92 & 80.79 & 2.16 & 35.92 & 80.79 & 1.91 & 31.81 & 71.15 \\
\hline \multirow[t]{2}{*}{3} & 1.05 & 17.54 & 98.32 & 1.05 & 17.54 & 98.32 & 1.63 & 27.18 & 98.32 \\
\hline & \multicolumn{9}{|c|}{ Exotic fruits } \\
\hline 1 & 2.67 & 44.45 & 44.45 & 2.67 & 44.45 & 44.45 & 2.55 & 42.55 & 42.55 \\
\hline 2 & 2.35 & 39.10 & 83.55 & 2.35 & 39.10 & 83.55 & 2.46 & 41.00 & 83.55 \\
\hline
\end{tabular}

Table 6 Matrix of the major principal component

\begin{tabular}{llllll}
\hline & Local fruits & \multicolumn{3}{c}{ Exotic fruits } \\
\hline & Component & & 3 & \multicolumn{3}{c}{ Component } \\
\hline $\mathrm{Cd}$ & 1 & 2 & 0.485 & 0.390 & 2 \\
$\mathrm{Cu}$ & 0.329 & -0.801 & -0.302 & -0.767 & -0.707 \\
$\mathrm{Fe}$ & 0.882 & 0.358 & 0.462 & 0.777 & -0.625 \\
$\mathrm{Ni}$ & 0.144 & 0.864 & 0.588 & 0.526 & -0.268 \\
$\mathrm{~Pb}$ & 0.808 & 0.038 & 0.213 & 0.947 & 0.736 \\
$\mathrm{Zn}$ & -0.568 & 0.759 & -0.349 & -0.386 & -0.030 \\
\hline
\end{tabular}

\subsection{Results of Multivariate Analysis}

The Principal component analysis (PCA) was employed to identify the factors responsible for the accumulation of trace metals in the studied local and exotic fruits and their relationships [70, 71]. The values extracted from the PCA are presented in Table 5. The Table indicates three major factors with Eigen values $>1$ with $98.32 \%$ of the total variance for the local fruits. Factor 1 contributed $44.86 \%$ of the total variance with significant positive loadings on $\mathrm{Cu}$, Zn, and a strong negative loading on $\mathrm{Pb}$ (Table 6). This represents the negative impact of agrochemicals on the quality of the studied local fruits [72, 73]. Factor 2 contributed $35.92 \%$ of the total variance with strong positive loadings on $\mathrm{Fe}, \mathrm{Pb}$ but strong negative loading on $\mathrm{Cd}$. This is the negative impact of natural factor and inorganic fertilizers on the quality of the local fruits as reported by Benson et al. [37] and Ebong et al. [74]. Factor 3 contributed 17.54\% of the total variance with a significant positive loading on $\mathrm{Ni}$ and a moderate positive loading on $\mathrm{Cd}$. This represents the impact of industrial wastes on the quality of the local fruits [75]. For the exotic fruits, PCA revealed two main factors with Eigen values greater than one with strong $83.55 \%$ of the total variance (Table 5 ). Factor one contributed $44.45 \%$ of the total variance with strong positive loadings on $\mathrm{Fe}, \mathrm{Ni}$, and $\mathrm{Pb}$ but a significant negative loading on $\mathrm{Cu}$ (Table 6). This denotes the negative impact of both the natural and anthropogenic factors on the metal load of exotic fruits [74]. Factor 2 contributed $39.10 \%$ of the total variance with significant negative loadings on $\mathrm{Cd}$ and $\mathrm{Cu}$ but strong positive loadings on $\mathrm{Ni}$ and $\mathrm{Zn}$ (Table 6). This represents the negative effects of organic wastes on the quality of the exotic fruits [16, 76]. This study has revealed the different sources of trace metals in the studied local and exotic fruits. The sources of trace metals in the local fruits were more than in the exotic ones. This might have resulted in the higher values of most of the metals reported in the local fruits. 


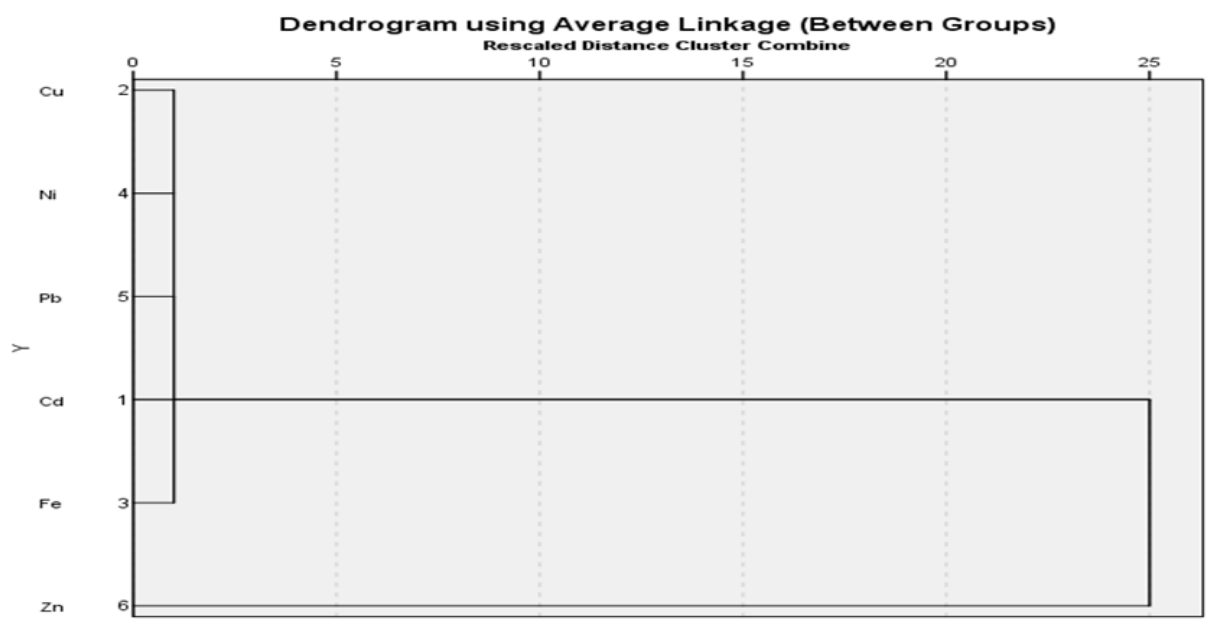

Figure 1 Hierarchical clusters formed among trace metals studied in the local fruits

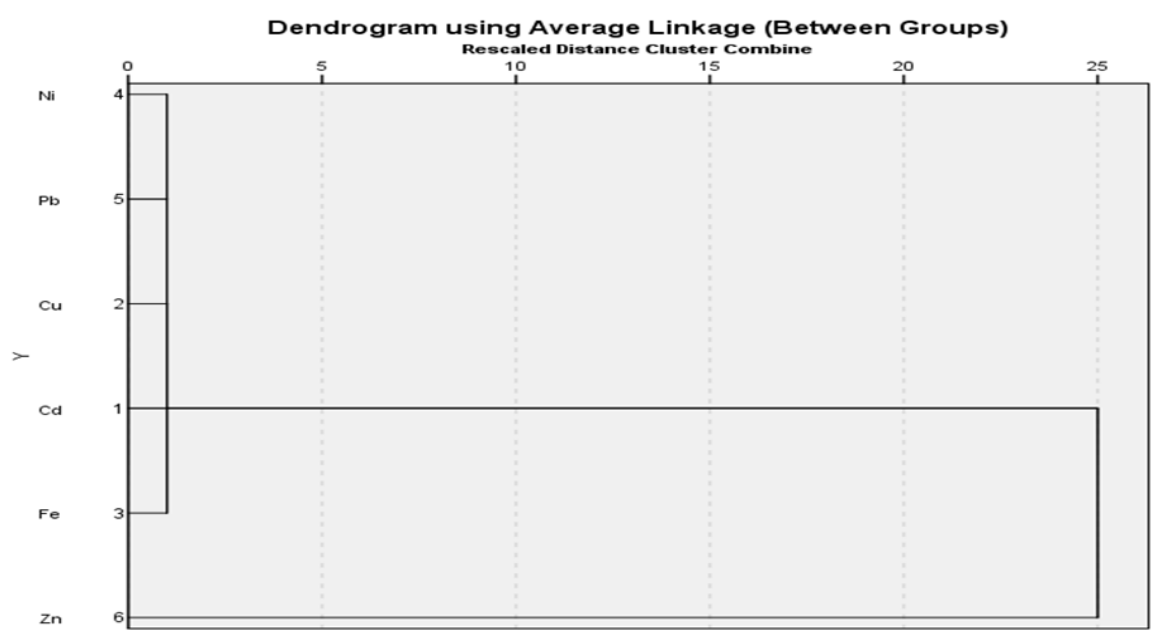

Figure 2 Hierarchical clusters formed among trace metals studied in the exotic fruits

The pair-wise affiliations between trace metals in the studied local and exotic fruits are demonstrated by Hierarchical cluster analysis (HCA) in figures 1 and 2, respectively. Both figures show two main clusters: (i) one linking all the trace metals together except $\mathrm{Zn}$, and (ii) the one linking only $\mathrm{Zn}$. This is an indication of a mutual source and similarities among trace metals in the first cluster [77]. Cluster two might have indicated a separate major source of Zn in the studied fruits from the other trace metals. The results of the HCA have also shown that irrespective of the source of the contaminants, their properties remain the same.

\section{Conclusion}

The study revealed the variations in the levels of $\mathrm{Cd}, \mathrm{Cu}, \mathrm{Fe}, \mathrm{Ni}, \mathrm{Pb}$, and $\mathrm{Zn}$ between the local and exotic fruits. It has also indicated the consequences of agrochemicals including organic and inorganic manures on the quality of the fruits cultivated. The cancer and non-cancer risks related to the consumption of these fruits have also been identified. The difference in the degree of exposure to carcinogens through the consumption of the locally sourced fruits and the exotic ones has also been indicated. The multivariate analysis employed in the study was able to identify the factors responsible for the accumulation of these trace metals in the studied fruits and it was mainly anthropogenic. The study reported higher levels of most of the metals in the locally sourced fruits than in the exotic ones. It also revealed that the consumers of local fruits are more susceptible to metal toxicity and its attendants' health problems than those consuming exotic fruits. Consequently, the extensive use of inorganic fertilizers and untreated organic wastes on farmlands should be controlled to avoid metal accumulation and the allied problems. 


\section{Compliance with ethical standards}

\section{Acknowledgments}

We wish to sincerely appreciate the efforts of the Technical Staff of the Department of Chemistry, University of Uyo, Uyo.

\section{Disclosure of conflict of interest}

There is no conflict of interest.

\section{References}

[1] Divrikli U, Horzum N, Soylak M and Elci L. (2006). Trace heavy metal contents of some spices and herbal plants from western Anatolia, Turkey. International Journal of Food Science and Technology, 41, 712-716.

[2] Manzoor J, Sharma M and Wani KA. (2018). Heavy metals in vegetables and their impact on the nutrient quality of vegetables: A review. Journal of Plant Nutrition, 41(13), 1744 - 1763.

[3] WHO. (2012). World Health Organization Evaluation of certain food additives and contaminants (41st Report of the Joint FAO/WHO Expert Committee on Food Additives). World Health Organization Technical Report Series No. 837.

[4] Mausi G, Simiyu G and Lutta S. (2014). Assessment of Selected Heavy Metal Concentrations in Selected Fresh Fruits in Eldoret Town, Kenya. J. Environ. Earth Sci., 4(3), 1-8.

[5] Sobukola OP, Awonorin SO, Idowu MA and Bamiro FO. (2008). Chemical and physical hazard profile of 'robo' processing - a street vended melon snack. Inter. J. Food Sci. Technol., 43(2), 237-242.

[6] Alzahrani HR, Kumakli H and Ampiah E. (2017). Determination of macro, essential trace elements, toxic heavy metal concentrations, crude oil extracts and ash composition from Saudi Arabian fruits and vegetables having medicinal values. Arabian Journal of Chemistry, 10(7), 906-913.

[7] Prashanth L, Kattapagari KK, Chitturi RT, Baddam VR and Prasad LK. (2015). "A review on role of essential trace elements in health and disease," Journal of NTR University of Health Sciences, 4, 75-85.

[8] Ikechukwu UR, Okpashi VE, Oluomachi UN, Paulinus NC, Obiageli NF and Precious O. (2019). Evaluation of heavy metals in selected fruits in Umuahia market, Nigeria: Associating toxicity to effect for improved metal risk assessment. Journal of Applied Biology \& Biotechnology, 7(04), 39 - 45.

[9] Rahim M, Ullah I, Khan A and Haris MRHM. (2016). "Health risk from heavy metals via consumption of foodcrops in the vicinity of District Shangla," Journal of the Chemical Society of Pakistan, 38(1), 177-185.

[10] Ali H, Khan E and Ilahi I. (2019). Environmental Chemistry and Ecotoxicology of Hazardous Heavy Metals: Environmental Persistence, Toxicity, and Bioaccumulation. Journal of Chemistry, 1 - 14.

[11] Khan S, Aijun I, Zhang S, Hu Q and Zhu YG. (2008). Accumulation of polycyclic aromatic hydrocarbons and heavy metals in lettuce grown in the soils contaminated with long-term wastewater irrigation. J. Hazard Material, 152(2), 506 - 515.

[12] Kooner RB, Mahajan VC and Dhillon WS. (2014). Heavy Metal Contamination in Vegetables, Fruits, Soil and WaterA Critical Review. International Journal of Agriculture, Environment \& Biotechnology, 7(3), 603-612.

[13] Mirecki N, Agič R, Šunić L, Milenković L and Ilić ZS. (2015). Transfer factor as indicator of heavy metals content in plants. Fresenius Environmental Bulletin, 24, 4212 - 4219.

[14] Hezbullah M, Sultana S, Chakraborty SR and Patwary MI. (2016). Heavy metal contamination of food in a developing country like Bangladesh: An emerging threat to food safety. Journal of Toxicology and Environmental Health Sciences, 8(1), 1-5.

[15] Onuoha SC. (2017). Assessment of Metal Contamination in Aquaculture Fish Ponds South Eastern, Nigeria. World Applied Sciences Journal, 35 (1), 124-127.

[16] Orisakwe OE, Oladipo 00, Ajaezi GC and Udowelle NA. (2017). Horizontal and Vertical Distribution of Heavy Metals in Farm Produce and Livestock around Lead-Contaminated Goldmine in Dareta and Abare, Zamfara State, Northern Nigeria. Journal of Environmental and Public Health, 1 - 12. 
[17] Khairiah T, Zalifah MK, Yin YH and Aminah A. (2004). The uptake of heavy metals by fruit type vegetables

[18] Kumar B, Smita K and Flores LC. (2017). Plant mediated detoxification of mercury and lead. Arabian Journal of Chemistry, 10, S2335 - S2342.

[19] Sulaiman FR and Hamzah HA. (2018). Heavy metals accumulation in suburban roadside plants of a tropical area (Jengka, Malaysia). Ecological Processes, 7(28), 1 -11.

[20] Zia MS and Khan MJ. (2008). Waste water use in agriculture and heavy metal pollution in soil plant system. Journal-Chemical Society of Pakistan, 30(3), 424-430.

[21] Khalid S, Shahid M, Bibi I, Sarwar T, Shah A and Niazi N. (2018). A review of environmental contamination and health risk assessment of wastewater use for crop irrigation with a focus on low- and high-income countries. International Journal of Environmental Research and Public Health, 15(5), 895.

[22] Pasha Q, Malik SA, Shaheen N and Shah MH. (2010). Comparison of Trace Elements in the scalp Hair of Malignant and Benign Breast Lesions Versus Healthy Women. Biol Trace Elem Res., 134(2), 16073.

[23] Elbagermi MA, Edwards HGM and Alajtal AI. (2012). Monitoring of heavy metal content in fruits and vegetables collected from production and market sites in the Misurata area of Libya. Analytical Chemistry, 1-5.

[24] Neal AP and Guilarte TR. (2012). Mechanisms of heavy metal neurotoxicity: Lead and manganese. J Drug Metab Toxicol, S5, 1-13.

[25] Ogunkunle AT, Bello OS and Ojofeitimi OS. (2014). Determination of heavy metal contamination of street-vended fruits and vegetables in Lagos state, Nigeria. Inter. Food Res. J., 21(5), 1725-1730.

[26] FAO/WHO. (2001). Codex Alimentarius Commission. Food additives and contaminants. Joint FAO/WHO Food Standards Program 2001; ALINORM 01/12A:1-289. Guiyang, PR China. Bull Environ Contam Toxicol., 80(5), 465468.

[27] Adedokun AH, Njoku KL, Akinola MO, Adesuyi AA and Jolaoso AO. (2016). Potential Human Health Risk Assessment of Heavy Metals Intake via Consumption of some Leafy Vegetables obtained from Four Market in Lagos Metropolis, Nigeria. J. Appl. Sci. Environ. Manage, 20(3), 530 - 539.

[28] Storelli MM. (2008). Potential human health risks from metals ( $\mathrm{Hg}, \mathrm{Cd}$, and $\mathrm{Pb}$ ) and polychlorinated biphenyls (PCBs) via seafood consumption: Estimation of target hazard quotients (THQs) and toxic equivalents (TEQs). Food Chemistry and Toxicology, 46, 2782-2788.

[29] Jan FA, Ishaq M, Khan S, Ihsanullah I, Ahmad I and Shakirullah M. (2010). A comparative study of human health risks via consumption of food crops grown on wastewater irrigated soil (Peshawar) and relatively clean water irrigated soil (lower Dir). Journal of Hazard Materials, 179, 612-621.

[30] WHO. (2018). World Health Organization "Obesity and overweight".

[31] USEPA. (2010). Integrated risk information system (I R I S). United States Environmental Protection.

[32] Cao S, Duan X, Zhao X, Wang B, Ma J, Fan D, Sun C, He B, Wei F and Jiang G. (2015). Health risk assessment of various metal(loid)s via multiple exposure pathways on children living near a typical lead-acid battery plant, China. Environ. Pollut., 200, $16-23$.

[33] USEPA (2020). USEPA Regional Screening Level (RSLs): User's Guide - Generic Tables.

[34] USEPA (2011). United States Environmental Protection Agency, Exposure Factors Handbook: 2011 Edition, EPA/600/R-090/052F.

[35] WHO/FAO. (2011). Joint report, Food standard programs Codex committee on contaminants in foods (CF/5 INF/1). Fifth Session, Rome, 64 - 89.

[36] Sobukola OP, Adeniran OM, Odedairo AA and Kajihausa OE. (2010). Heavy metal levels of some fruits and leafy vegetables from selected markets in Lagos, Nigeria. Afr. J. Food Sci, 4(2), 389-393.

[37] Benson NU, Anake WU and Etesin UM. (2014). Trace Metals Levels in Inorganic Fertilizers Commercially Available in Nigeria. Journal of Scientific Research \& Reports, 3(4), 610 - 620.

[38] Morgan JN. (1999). Effects of Processing on Heavy Metal Content of Foods. Impact of Processing on Food Security, $195-211$.

[39] Bost M, Houdart S, Oberli M, Kalonji E, Huneau JF and Margaritis I. (2016). Dietary copper and human health: current evidence and unresolved issues. J Trace Elem Med Biol., 35, 107-115. 
[40] Ezeonyejiaku CD and Obiakor MO. (2017). A Market Basket Survey of Horticultural Fruits for Arsenic and Trace Metal Contamination in Southeast Nigeria and Potential Health Risk Implications. Journal of Health \& Pollution, $7(15), 40-50$.

[41] Aydinalp C and Marinova S. (2012). Concentration of $\mathrm{Cu}$ and $\mathrm{Zn}$ in some fruits and vegetables grown in north western Turkey. Bulgarian Journal of Agricultural Science, 18 (5), 749-751.

[42] Itanna F. (2002). Metals in leafy vegetables grown in Addis Ababa and toxicology implications. Ethiopian J. Health Develop, 16, 295-302.

[43] Mehari TF, Greene L, Duncan AL and Fakayode SO. (2015). Trace and Macro Elements Concentrations in Selected Fresh Fruits, Vegetables, Herbs, and Processed Foods in North Carolina, USA. Journal of Environmental Protection, $6,573-583$.

[44] Yami SG, Chandravanshi BS, Wondimu T and Abuye C. (2016). Assessment of selected nutrients and toxic metals in fruits, soils and irrigation waters of Awara Melka and Nura Era farms, Ethiopia. SpringerPlus, 5, 734 -747.

[45] Alvarez-Fernandez A, Paniagua P, Abadia J and Abadia A. (2003). Effects of Fe Deficiency Chlorosis onYield and Fruit Quality in Peach (Prunus Persica L. Batsch). J. Agric Food Chem., 51(19), 5738 - 5744.

[46] Rout GR and Sahoo S. (2015). Role of iron in plant growth and metabolism. Reviews in Agricultural Science, 3, 1 24.

[47] Rieuwerts JS, Thornton I, Farago ME and Ashmore MR. (1998). Factors influencing metal bioavailability in soils: preliminary investigations for the development of a critical loads approach for metals, Chemical Speciation \& Bioavailability, 10(2), 61-75.

[48] Nouri J, Khorasani N, Lorestani B, Karami M, Hassani AH and Yousefi N. (2013). Accumulation of heavy metals in soil and uptake by plant species with phytoremediation potential. Environmental Earth Sciences, 59(2), 315-323.

[49] Guerra F, Trevizam AR, Muraoka T, Marcante NC and Canniatti-Brazaca SG. (2012). Heavy metals invegetables and potential risk for human health. Science and Agriculture, 69, 54-60.

[50] Omoyajowo KO, Njoku KL, Babalola 00 and Adenekan OA. (2017). Nutritional composition and heavy metal content of selected fruits in Nigeria. Journal of Agriculture and Environment for International Development JAEID, 111(1), 123-139.

[51] Rumsey DJ. (2002). Discussion: Statistical literacy: Implications for teaching, research, and practice. International Statistical Review, 70(1), 32-36.

[52] Radwan MA and Salama AK. (2006). Market basket survey for some heavy metals in Egyptian fruits and vegetables. Food and Chemical Toxicology, 44 (8), 1273 - 1278.

[53] Ihesinachi K and Eresiya D. (2014). Evaluation of heavy metals in orange, pineapple, avocado pear and pawpaw from a farm in Kaani, Bori, Rivers State Nigeria. International Research Journal of Public and Environmental Health,1(4), 87-94.

[54] Rahman MM, Azirun SM and Boyce AN. (2013). Enhanced Accumulation of Copper and Lead in Amaranth (Amaranthus paniculatus), Indian Mustard (Brassica juncea) and Sunflower (Helianthus annuus). PLoS ONE, 8(5), e62941.

[55] Plum LM, Rink L and Haase H. (2010). The Essential Toxin: Impact of Zinc on Human Health. International Journal of Environmental Research and Public Health, 7(4), 1342-1365.

[56] Sharma A, Patni B, Shankhdhar D and Shankhdhar SC. (2013). Zinc - An Indispensable Micronutrient. Physiol Mol Plants, 19(1), 11-20.

[57] World Health Organization. (WHO). (2010). Quantifying Environmental Health Impacts. World Health Organization, Geneva.

[58] FAO/WHO. (1999). Joint Expert Committee on Food Additives, "Summary and Conclusions", in proceedings of the 53rd Meeting of Joint FAO/WHO Expert Committee on Food Additives, In: 53rd meeting, Rome, Italy.

[59] Wang X, Sato T and Baoshan X. (2005). Health risk of heavy metals to the general public of Tianjin, China via consumption of vegetables and fish. Sci Total Environ., 350, 28-37.

[60] World Health Organization. (WHO). (2004). Evaluation of certain food additives and Contaminants. In: Sixty-First Report of the Joint FAO/WHO Expert Committee on Food Additives. WHO, Geneva, Switzerland. (WHO Technical Series, 922). 
[61] Goldhaber SB. (2003). Trace element risk assessment: essentially vs. toxicity. Regul Toxicol Pharmacol., 38, 232242.

[62] Adewole MB and Uchegbu LU. (2010). Properties of soils and plants uptake within the vicinity of selected automobile workshops in Ile-Ife, Southwestern Nigeria. Ethiop J Environ Stud Manage, 3, 23-28.

[63] Tuzen M. (2003). Determination of heavy metals in soil, mushrooms and plant samples by AAS. Microchem J., 74, 289-297.

[64] Bagdatlioglu N, Nergiz C and Ergonul PG. (2010). Heavy metal levels in leafy vegetables and some selected fruits. Journal of Consumer Protection and Food Safety, 5, 421- 428.

[65] Arias VO, Som LV, Rodríguez VQ, Romero RG, Muñoz N, Alarcón MN and Vique CC. (2015). Nickel in food and influencing factors in its levels, intake, bioavailability and toxicity: a review. CyTA - Journal of Food, 13(1), 87101.

[66] Roohani N, Hurrell R, Kelishadi R and Schulin R. (2013). Zinc and its importance for human health: An integrative review. Journal of Research in Medical Science, 18(2), 144 - 157.

[67] Man YB, Sun XL, Zhao YG, Lopez BN, Chung SS and Wu SC. (2010). Health risk assessment of abandoned agricultural soils based on heavy metal contents in Hong Kong, the world's most populated city. Environment International, 36(6), 570-576.

[68] Li Z, Zhang D, Wei Y, Luo L and Dai T. (2014). Risk assessment of trace elements is cultured from freshwater fishes from Jiangxi Provence, China. Environ Monit Assess., 186, 2185 - 2194.

[69] IARC. (International Agency for Research on Cancer). (2011). IARC (International Agency for Research on Cancer) Agents Classified by the IARC Monographs, 1-102.

[70] Yang P, Yang M, Mao R and Shao H. (2014). Multivariate-Statistical Assessment of Heavy Metals for Agricultural Soils in Northern China. The Scientific World J., 1 - 7.

[71] Paladino 0, Moranda A and Sevedsalehi M. (2017). A Method for Identifying Pollution Sources of Heavy Metals and PAH for a Risk-Based Management of a Mediterranean Harbour. Scientifica (Cairo), 1-9.

[72] Sumner ME. (2000). "Beneficial use of effluents, wastes, and biosolids," Communications in Soil Science and Plant Analysis, 31(11-14), 1701-1715.

[73] Azeez JO, Hassan OA and Egunjobi PO. (2011). Soil Contamination at Dumpsites: Implication of Soil HeavyMetals Distribution in Municipal Solid Waste Disposal System: A Case Study of Abeokuta, Southwestern Nigeria. Soil and Sediment Contamination: An International Journal, 20(4), 370 - 386.

[74] Ebong GA, Ettesam ES and Dan EU. (2020). Impact of Abattoir Wastes on Trace Metal Accumulation, Speciation, and Human Health-Related Problems in Soils Within Southern Nigeria. Air, Soil, and Water Research, 13, 1-14.

[75] Wu YF, Liu CQ and Tu CL. (2008). Atmospheric deposition of metals in TSP of Guiyang, PR China. Bull Environ Contam Toxicol., 80(5), 465-468.

[76] Olabanji IO, Oluyemi EA and Obianjuwa EI. (2015). Nondestructive analysis of dumpsite soil and vegetable for elemental composition. Journal of Environmental Chemistry and Ecotoxicology, 7(1), 1-10.

[77] Yang Z, Lu W, Long Y, Bao X and Yang Q. (2011). Assessment of heavy metals contamination in urban topsoil from Changchun City, China. J. Geochemical Explor, 108, 27-38.

\section{How to cite this article}

Ebong GA, Etuk HS, Dan EU and Ekpo KJ. (2020). Variations in the levels, source, cancer and non-cancer risks of trace metals in the local and exotic fruits. World Journal of Advanced Research and Reviews, 6(3), 275-288. 